Discussion Paper No. 97-18

New Technology-Based Firms in Germany:

A Survey of the Recent Evidence 
Georg Licht and Eric Nerlinger 


\section{Non-technical summary}

The paper provides an overview of some of the recent research on New Technology Based Firms in Germany and covers issues from firm formation dynamics, the regional distribution and location characteristics of NTBFs, the participation of these firms in technology transfers, and their participation in public support programmes. It has been shown that after the decline in the number of technology-based start-ups that was apparent between 1990 and 1992, there has been a small increase in the annual number of new firm formations in the high-tech industries and in technology-intensive services, but it is also apparent that, compared with the number of formations in the late 1980s, the number of firm formations in the very-high-tech manufacturing sectors has remained at a lower level since 1992. With regard to the results of analyses on the regional clustering of NTBFs and their locational considerations, one of the major findings was that the regional $R \& D$ endowment of universities, technical colleges and nonuniversity R\&D-labs has a large impact on the number of new firms in the region, but that this impact also varies with the institute's field of specialisation. In contrast, the R\&D activities of private firms do not appear to have an influence on the number of NTBFs in a region. The importance of the regional endowment of $\mathrm{R} \& \mathrm{D}$ facilities is also important with regard to technology transfer. The perceived importance of NTBFs for technology transfer and for the creation of employment is indicated by the number and the volume of public promotion schemes which are offered by federal ministries as well as by the ministries and institutions of the Bundeslaender. However, due to the huge volume and sometimes confusing complexity of the supporting schemes, a lot of small and medium-sized firms have neither the time nor money to gather and process all the available information about these programmes. Consequently, they may not apply for the support that is available at the level of the Laender, the federal level, or at the EC level. As a response to this, a reduction and simplification of the support schemes is planned in Germany. Apart from benefiting the firms, this may also benefit providers of support, including banks, by the imposition of clear standards of support. 


\title{
New Technology-Based Firms in Germany: A Survey of the Recent Evidence
}

\author{
by \\ Georg Licht and Eric Nerlinger \\ Zentrum fuer Europaeische Wirtschaftsforschung, Mannheim \\ (Centre for European Economic Research)
}

June 1997

\begin{abstract}
The Importance and Contribution of new technology-based Firms (NTBFs) to long term economic development is at the center of a controversial debate. This paper provides an overview of the current status of research on various issues concerning NTBFs in Germany. The issues covered include the incidence of start-ups firms in Germany's technology-intensive sectors and their regional clustering. The review also shows that NTBFs play an important role with regard to the transfer, adoption and diffusion of technology. The public support and policy initiatives for new technology-based firms in Germany are also discussed.

\section{Acknowledgement}

Financial support from the 'Deutsche Forschungsgemeinschaft' is gratefully acknowledged. We are indebted to David Storey and Bruce Tether for detailed comments on an early version of this paper and to Andreas Fier and Georg Berger for their support and comments. All errors and omissions are - of course - our own.
\end{abstract}




\section{Introduction}

During the past decade, small and medium-sized companies in general and new technology-based firms (NTBFs) in particular have attracted growing interest from academics and politicians. One indicator of this interest is public expenditure on new technology-based firms. In Germany, federal funding for the indirect promotion of NTBFs has risen from 45.9 million DM in 1991 to almost 82 million DM in 1993 (BMBF, 1996, p. 97). Public awareness of NTBFs arose in the early eighties, when several traditional industries were in decline and some fast growing new industries began to emerge. NTBFs have therefore been regarded as an answer to ongoing structural changes; they are seen as an important source of new employment and important promoters of technological change and innovation in the German economy. The creation of such firms has been stimulated by public policies, such as the pilot scheme for the 'Promotion of New Technology-based Firms' which was initiated by the Federal Ministry of Research (BMBF, 1996; Kulicke et al., 1993).

Whilst it is acknowledged that large numbers of jobs are created in small and medium-sized firms (SMEs), it should also be recognised that many jobs are lost by the closure of smaller firms (Davis et al., 1996; Gerlach and Wagner, 1997). The current debate focuses on the contribution NTBFs have made to employment, to technological innovation and to the diffusion of new technological knowledge. Some argue that new companies of this kind are rare, so their contribution to overall employment and national technological performance is marginal (Berndts and Harmsen, 1985; Sternberg, 1988), but others suggest that new technology-based firms are much more important, being the primary source of new employment and the engine of technological change and economic growth (Kulicke et al., 1993). Famous American firms like Microsoft, and German firms like SAP, are often taken as being illustrative of the potential of NTBFs. However, the debate about the potential of NTBFs and other small firms for employment creation goes a long way back, to the work of David Birch in the late 1970s (Birch, 1979), and since this time it has become clear that the expectations of employment creation by NTBFs and other small firms, as the solution for high rates of unemployment, has been exaggerated. Presently, the debate is more concentrated on the role of NTBFs and small firms in innovation than on employment.

The purpose of this paper is to provides an overview of the current status of research on NTBFs in Germany, and to outline economic policy initiatives relating to NTBFs in Germany. Section 2 of the paper deals with the incidence of new firm start-ups in Germany's technology-intensive sectors, with separate analyses for the 'East' and 'West' of the country to take account of the real differences which still exist between what were two different countries. This is followed, in Section 3, by an empirical analysis of the regional clustering in the formation of new technologybased firms. Section 4 focuses on the significance of new technology-based firms 
for the transfer, adoption and diffusion of technology. As will be seen, the nature of technology transfer and the role of NTBFs in the adoption and diffusion of technologies differs according to their stage of corporate development. The fifth section, which contains a discussion of the public support and policy initiatives for new technology-based firms in Germany, concludes the study.

\section{NTBFs in East and West Germany}

One of the first studies on new technology-based firms in the USA, the United Kingdom and Germany was conducted by the management consultants Arthur D. Little (Little, 1977). In each of these countries, the number of NTBFs was found to have risen substantially until the mid-seventies. This trend is corroborated by the results of a study by Berndts and Harmsen (1985) on the city of Berlin, which showed that between 1978 and 1983 more than three times as many innovative firms ${ }^{1}$ were established as between 1968 and 1974 (1968 - 1974: 21; 1974 - 1978: 33; 1978 -1983: 71).

Compared with other industrialised countries, Germany is a special case in terms of the increase in the number of new firms during the late 1980s due to Germany's reunification in 1989. This is because reunification had specific one-off effects, notably the opening-up of a new, less developed, market, which led to a boom in business activity and this is directly reflected in the large number of new firms, including new technology-based firms in particular, that were established in the period following reunification (Nerlinger, 1996; Felder et al., 1997a, 1997b). But the data on start-ups in the technology-intensive branches of Germany's manufacturing and service sectors show that the boom in new firm formations that was triggered by reunification has been followed by a sharp decline. More recently, however, there are indications that, in general, new firm formations in these sectors are beginning to recover. Nerlinger (1995) shows that the growth rate, in terms of the number of new firms, in High-tech Services ${ }^{2}$ and 'high-tech manufacturing industries' (defined as industries with a R\&D-intensity of between 3.5 and 8.5 percent) is higher than that elsewhere in the manufacturing sector. However, this does not apply to the 'very-high-tech manufacturing industries' (i.e., those with a R\&D-intensity above 8.5 percent), where the number of firm formations has increased only slightly, and the rate of increase has lagged behind the general trend. Consequently the proportion of new firms in the 'very-high-tech industries' relative to all new firms in the manufacturing sector fell from 8.1 percent in 1990 to less

1 Berndts and Harmsen (1985) analyse firms which were founded by former employees of public R\&D institutions. It should be noted that employment in public R\&D facilities and universities increased rapidly in the late sixties and early seventies.

2 High tech services comprise knowledge-intensive activities such as 'Computer Services', 'Research and Development in Natural Sciences and Engineering' and 'Higher Education Institutes and Laboratories'. A detailed description of the activities involved is provided by Nerlinger and Berger (1995a). 
than 6.7 percent in 1995, while 'high-tech industries' increased their share from 12.9 percent to 14.2 percent over the same period. The evidence for 1996 indicates that the number of new technology-based firms is continuing to rise (see Nerlinger, 1997).

\section{Figure 1: Number of Firm Formations in Technology-Intensive Industries in West Germany from 1985-1995}

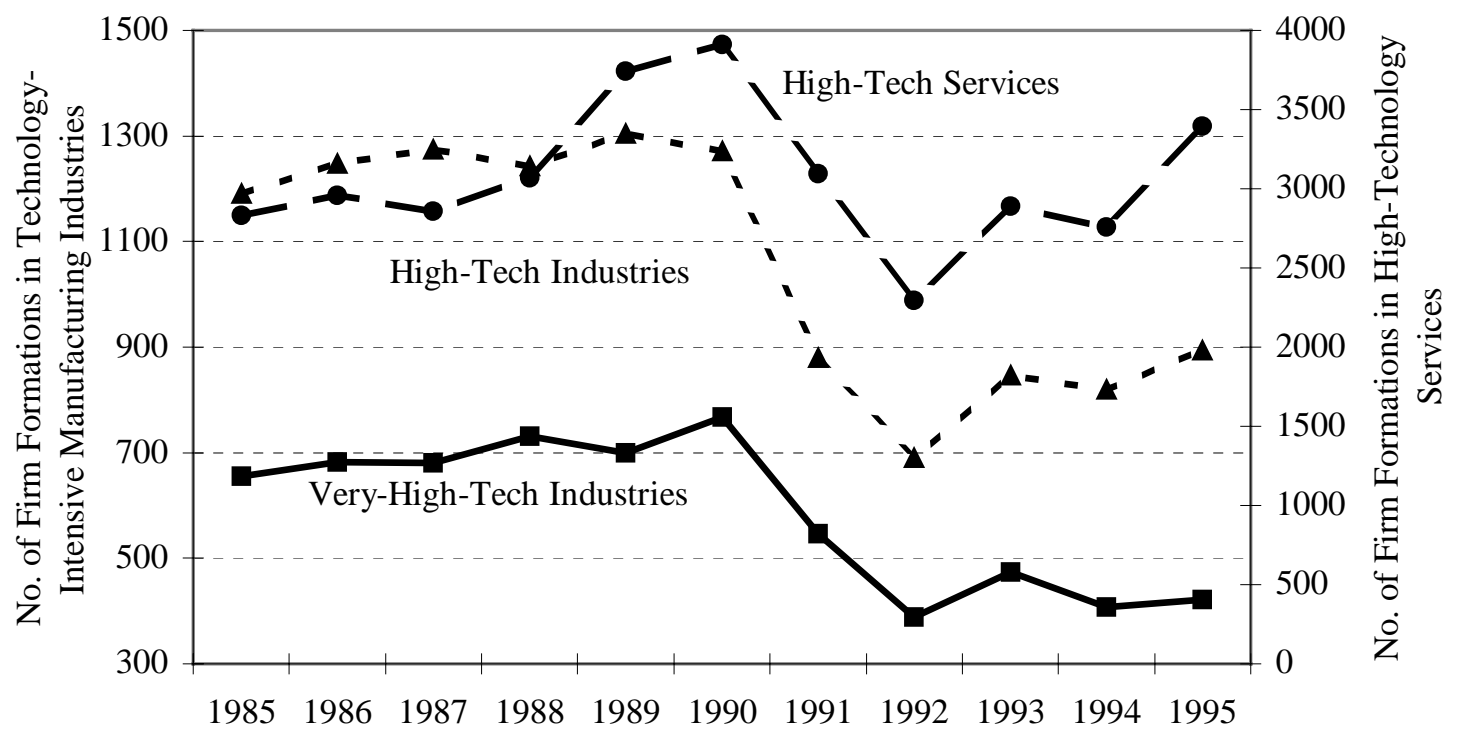

"High-Tech Services": Defined as knowledge-intensive service sector (see Nerlinger and Berger, 1995a) "Very-High-Tech Industries": Manufacturing Industries with a R\&D intensity of more than 8.5 percent "High-Tech Industries": Manufacturing Industries with a R\&D intensity of between 3.5 and 8.5 percent

Source: ZEW Formation Panel (West)

Overall, however, new technology-based firms constitute only a small proportion of all firm formations. ${ }^{3}$ Sternberg (1988) and the Verband der Vereine Creditreform (1985) - the largest credit rating agency in Germany - judge that only between one and five percent of all new firms in Germany's manufacturing sector are based on advanced technologies; this corresponds to the formation of between 250 and 400 new technology-based firms a year. Similarly, on the basis of Commercial Register entries, Kulicke (1987) estimates the number of technology-based firm formations between 1973 and 1984 to have been about 2,000, whilst Gerybadze (1991) postulates that out of the about 300 technology-based firm formations a year (i.e. firms with annual R\&D expenditures of more than 100,000 DM) in Germany, only 120 can be described as R\&D-intensive firm formations (i.e., those with annual $R \& D$ expenditures in excess of $250,000 \mathrm{DM}$ ).

3 Note that industry-specific definitions (defined by products and/or processes at the firm level) of new technology-based firms may overestimate the number of NTBFs (Nerlinger and Berger, 1995a). 
The trends in both the absolute and the relative start-up statistics in the technologyintensive sectors seems to be slightly correlated with the business cycle. This is particularly apparent in Germany during the recessions of the early eighties and early nineties, and in the intervening boom years. In view of the factors applying immediately after German reunification, the two recessionary phases are dealt with separately. The period 1980 - 1982 is designated 'Recession Phase I', the period 1991 - 1992 'Recession Phase II', and the period 1983 - 1990 the 'Boom Phase' (Sachverstaendigenrat, 1993). Analysis shows that, in the non-technology-based sectors of the economy, the business cycle exerts only a slight influence on the average firm formation and firm mortality rates. This prompts the hypothesis that in the second recession phase the after-effects of reunification were still being felt. With the exception of the more substantial decline in formation rates during Recession Phase I, this pattern also applies to the high-tech manufacturing sector and to some areas of the service sector. For very-high-tech firms, however, formation rates fell in both recession phases to a level significantly below the corresponding figure in the boom phase. In short, this means that in the very-hightech industries fewer firms and enterprises were formed in recession phases, and that at the same time more firm and enterprise closures occur (Fritsch, 1990; Koschatzky et al., 1992).

Table 1: Firm formation in technology-intensive sectors in relation to the manufacturing sector $(1992-1995$, in \%)

\begin{tabular}{l|rrrr|rrrr} 
& \multicolumn{4}{|c|}{ 'East' Germany } & \multicolumn{4}{c}{ 'West' Germany } \\
& 1992 & 1993 & 1994 & 1995 & 1992 & 1993 & 1994 & 1995 \\
\hline \hline Very-high-tech Industries & 6.2 & 5.4 & 5.6 & 5.7 & 7.5 & 7.9 & 6.1 & 5.6 \\
High-Tech Industries & 11.9 & 12.7 & 13.0 & 12.8 & 10.6 & 12.6 & 13.1 & 13.8 \\
Other Manufacturing & 81.9 & 81.9 & 81.4 & 81.5 & 81.9 & 79.5 & 80.8 & 80.6 \\
\hline \hline
\end{tabular}

Source: ZEW Formation Panel (East/West)

The increase in the number of start-ups in the mid-eighties coincided with an aboveaverage increase in the number of new jobs. The same holds for the first two years after reunification until late 1991, when the annual number of new firms started to decline slightly. However, the current trend in formation statistics in the technology-intensive industries shows an ongoing increase in the number of new jobs (Beise et al., 1997). In all three classes of manufacturing, and in the service sector, a fall in employment in new enterprises which employ fewer than 50 people is noticeable in 1991 and 1992. This decline was 2.8 percent in the 'other' manufacturing sector (i.e., the non-technology-intensive part of manufacturing), a spectacular 18.3 percent in the high-tech industries, 6 percent in the very-high-tech industries, and 1.4 percent in the technology-intensive part of the service sector. 
Table 2: Formation and mortality rates in boom and recession phases in the west of Germany (in \%)

\begin{tabular}{|c|c|c|c|c|c|c|}
\hline & \multicolumn{2}{|c|}{$\frac{\text { Recession-Phase I }}{(1980-1982)}$} & \multicolumn{2}{|c|}{$\frac{\text { Boom-Phase }}{(1983-1990)}$} & \multicolumn{2}{|c|}{$\frac{\text { Recession Phase II }}{(1991-1992)}$} \\
\hline & $\begin{array}{l}\text { Formation } \\
\text { Rate }\end{array}$ & $\begin{array}{l}\text { Mortality } \\
\text { Rate }\end{array}$ & $\begin{array}{l}\text { Formation } \\
\text { Rate }\end{array}$ & $\begin{array}{l}\text { Mortality } \\
\text { Rate }\end{array}$ & $\begin{array}{l}\text { Formation } \\
\text { Rate }\end{array}$ & $\begin{array}{l}\text { Mortality } \\
\text { Rate }\end{array}$ \\
\hline Very-High-Tech Industries & 10.9 & 9.5 & 11.9 & 8.7 & 10.8 & 9.7 \\
\hline High-Tech Industries & 8.1 & 7.4 & 8.9 & 7.6 & 9.2 & 7.4 \\
\hline Other Manufacturing & 8.2 & 8.8 & 8.5 & 8.7 & 8.9 & 8.6 \\
\hline High-Tech Services & 14.7 & 12.3 & 15.2 & 12.4 & 14.8 & 11.8 \\
\hline
\end{tabular}

The average number of Start-Ups (Closures) with regard to the technology sectors is 1,165.5 (866.9) in the Very-High-Tech Industries, 2,579.8 (2,161.1) in the High-Tech Industries, 26,627.8 $(27,085.8)$ in Other Manufacturing and 81,942.0 $(69,190.7)$ in the High-Tech Services.

Source: Employment Statistics Register of the Federal Office for Labour, Sachverstaendigenrat (1993).

Besides the jobs created by new firms, the jobs lost by firm closures also constitutes a major factor affecting employment in the economy as a whole. Job gains from firm formations are offset by job losses from closures. The net employment creation figures for new firms and closures have been positive for the 'very-high-tech' and 'high-tech' industrial sectors, and for the service sector over the period from 1979 to 1992. In contrast, over the period of as a whole, employment created in new firms in the 'other' manufacturing sectors failed to compensate for the corresponding employment lost through closures.

A clear difference can be seen between the technology-based and 'other' industries in terms of the employment created and that lost over the period of analysis. In 1979, the 'other' manufacturing industries increased their net employment by 21,250 , but in the following years, until reunification, job losses from firm closures exceeded the number of jobs created by start-up firms. slight recovery triggered by reunification is evident for the technology-based industries. The term "recovery" in this context, however, reflects part of ongoing developments in the very-high-tech and high-tech sectors, where more jobs were created in new enterprises than were lost by firm mortalities throughout the period from 1979 to 1991. 
Table 3: Number of employees in start-ups and closures in West Germany (1979-1992)

\begin{tabular}{|c|c|c|c|c|c|c|c|c|}
\hline Year & \multicolumn{2}{|c|}{$\frac{\text { Very-High-Tech }}{\underline{\text { Industries }}}$} & High-Tech & Industries & \multicolumn{2}{|c|}{ Other Manufacturing } & \multicolumn{2}{|c|}{ High-Tech Services } \\
\hline 1979 & 3,220 & 2,130 & 7,490 & 6,420 & 94,600 & 73,350 & 145,950 & 114,830 \\
\hline 1981 & 3,540 & 3,120 & 8,430 & 7,810 & 89,360 & 105,070 & 160,330 & 140,860 \\
\hline 1983 & 3,220 & 2,790 & 8,410 & 8,430 & 81,590 & 91,170 & 145,770 & 128,910 \\
\hline 1985 & 4,080 & 2,910 & 9,550 & 8,220 & 86,180 & 98,340 & 159,710 & 155,090 \\
\hline 1987 & 4,200 & 3,180 & 10,300 & 7,280 & 84,370 & 83,660 & 184,890 & 128,410 \\
\hline 1989 & 4,320 & 3,370 & 11,150 & 8,630 & 84,070 & 84,400 & 177,690 & 140,010 \\
\hline 1990 & 4,860 & 3,650 & 12,770 & 8,260 & 92,360 & 86,010 & 207,760 & 151,520 \\
\hline 1991 & 5,000 & 3,810 & 12,200 & 8,990 & 94,690 & 90,710 & 213,250 & 156,170 \\
\hline 1992 & 4,700 & n.a. & 9,970 & n.a. & 92,040 & n.a. & 210,330 & n.a. \\
\hline
\end{tabular}

a) Defined as establishments that did not appear in the employment database in the previous year.

b) Defined as establishments which did not appear in the employment database in the subsequent year. The figures depend crucially on the definition of 'start-up' and 'closure' used. Bellmann et al. (1997) argue that the number of new establishments decreases by about $26 \%$ if the underlying definition is changed from 'not occuring one year before' to 'not occuring in the last two years'. The same holds for closures. All figures rounded to the nearest 10

Source: Nerlinger (1995), Employment Statistics Register of the Federal Office for Labour

Overall, the direct contribution of new technology-based firms to employment in Germany appears to be limited. However, whilst many new firms do not survive beyond their first few years - a fact not shown by firm formation statistics or in statistics on the number of jobs created by new firms - other firms have been able to increase their workforce substantially within a short period of time (Gerlach and Wagner, 1997).

Table 4: Some Rapid Growth NTBFs in Germany

\begin{tabular}{l|c|c|c}
\multicolumn{1}{c|}{ Firm } & Foundation Year & $\begin{array}{c}\text { No. of Employees } \\
\text { (in 1995) }\end{array}$ & $\begin{array}{c}\text { Turnover, in Mill. DM } \\
\text { (in 1995) }\end{array}$ \\
\hline \hline SAP & 1972 & 6,857 & 2,694 \\
SCHNEIDER \& KOCH & 1980 & 170 & 76 \\
QIAGEN & 1984 & 110 & 26 \\
MICRONAS & 1990 & 300 & 75 \\
MOBILCOM & 1991 & 170 & 197 \\
\hline \hline
\end{tabular}

Source: CREDITREFORM, 1997; Hoppenstedt, 1997 
Table 4 provides a few examples of some recently established rapid growth technology-based firms in Germany. However, it should be remembered that when it comes to new technology-based firms, the indirect, more qualitative stimuli for technological change in the national economies are also of major importance.

\section{The Regional Characteristics and Location of NTBFs}

The major influences on the location of new technology-based firms have been analysed and described in numerous studies covering the west of Germany and recently the east of the country as well. These studies usually provide detailed information on the economic (e.g. availability of qualified employees) and infrastructural (e.g. universities, transportation links, etc.) factors involved.

Picot et al. (1989) identified proximity to the founder's place of residence to be the most important influence on the choice of location, with more than 70 percent of the young, innovative firms in their survey identifying this as a key locational determinant. Links to universities and the surrounding industrial environment were the next most important factors, although these were some way behind (Sternberg, 1988; Sternberg et al., 1996). Similar attitudes have been revealed by Berndts and Harmsen (1985), which found that 82 percent of the founders of NTBFs, defined as innovative firms with close relations to research institutions, sought a location less than $50 \mathrm{~km}$ away from their 'parent' research institutions.

Table 5: Influencing factors for the location choice of innovative firm founders

\begin{tabular}{l|c}
$\begin{array}{c}\text { New firm's location } \\
\text { (multiple answers possible) }\end{array}$ & $\begin{array}{c}\text { Mentions } \\
\text { (in \%) }\end{array}$ \\
\hline \hline Place of residence & $71.2 \%$ \\
Links to university & $30.8 \%$ \\
Industrial environment & $30.8 \%$ \\
No specific locational factors & $9.6 \%$ \\
Other & $36.5 \%$ \\
\hline \hline
\end{tabular}

The "Other" heading subsumes various locational factors like favourable rents, location-specific tax incentives, precise knowledge of the regional market, better access to subsidies.

Source: Picot et al. (1989, p. 167)

Besides universities, technical colleges and contacts with other companies, relationships with customers have also been found to be a significant consideration when founders of technology-based firms choose where to start-up. Kulicke (1987) shows that it is primarily large companies with more than 1,000 employees that are particularly important customers for NTBFs, whilst public institutions are less 
important. ${ }^{4}$ Another important locational consideration for new technology-based firms is the infrastructural advantages of the region or city concerned. It emerges that, in addition to business-related factors, the availability of residential and leisure amenities, a region's overall image and its cultural facilities play a significant role, although the contribution of these factors is hard to evaluate (Henckel and Hollbach, 1991).

\subsection{Regional distribution of NTBFs in the east and west of Germany}

The regional distribution, between 1993 and 1995, of innovative young firms, defined as start-up manufacturing firms with a R\&D-intensity above 3.5 percent and high-tech Service start-ups, shows substantial differences between the counties ("Kreise") of the west of Germany in terms of their density, industry-specific structure and sectoral distribution. In terms of location there is a broad belt of NTBF start-ups in the west of Germany, extending roughly along the course of the Rhine from the Ruhr down to the southern part of Baden-Wuerttemberg. The areas around Duesseldorf, Essen and Frankfurt, and the southern part of BadenWuerttemberg emerge as particularly frequent locations for establishing high-tech firms (Kulicke, 1987; Sternberg, 1995; Grotz, 1989; Berger and Nerlinger, 1997; Felder et al., 1997b)

By contrast there are other areas, predominantly rural in character, which are much less successful in meeting the locational requirements of technology-intensive firms. Particularly in the north of Germany, for example, Laender like SchleswigHolstein and Lower Saxony exhibit a low absolute number of technology-intensive start-ups, although cities like Hamburg, Bremen or Hannover are exceptions. There is also a significantly below-average number of new technology-based firms in most of the eastern counties of Lower Saxony, Hesse and Bavaria. Overall, the absolute number of start-ups in technology-intensive sectors is particularly high in large cities and agglomerations; this might be explained by their above-average supply of qualified staff, their relatively strong $R \& D$ infrastructure ${ }^{5}$ and advanced transportation links (Harhoff, 1995; Nerlinger, 1997).

4 In the context of customer-base, Fritsch (1990) concludes that in comparison to non-technology-based firms, the proportion of exporting companies is greater amongst new technology-based firms.

5 This includes universities, technical colleges ('Fachhochschulen'), (large) private firms with R\&D facilities, non-university research institutions (e.g. Fraunhofer Society, Max Planck Society, National Research Centres). 
Figure 2: Locations of new technology-based firms in Germany (1993-1995)

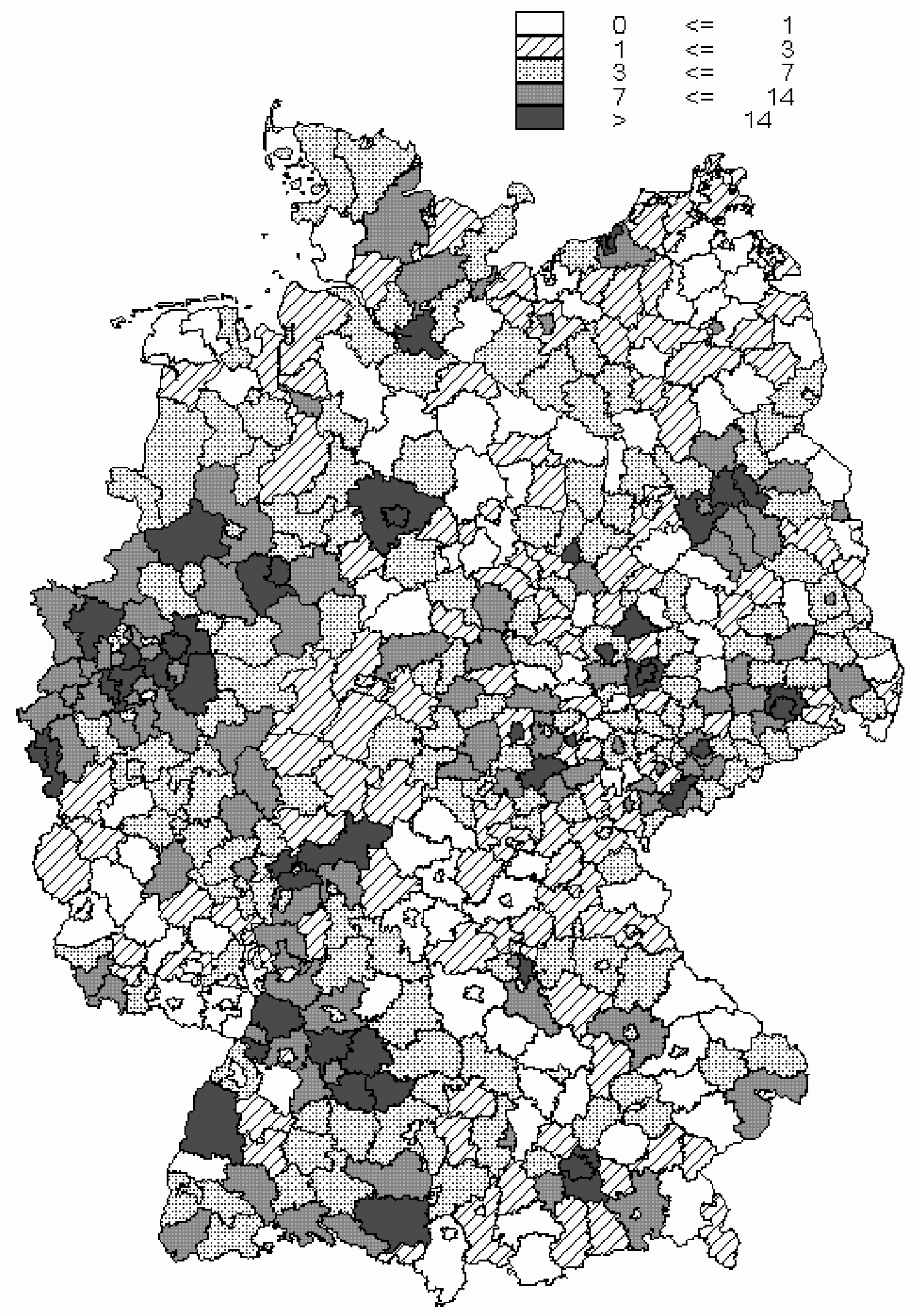

Source: ZEW Formation Panel (East/West) 
Scaling the absolute start-up figures against employment, the labour force or the population, reveals that technology-based start-up rates are highest in the more peripheral regions of core cities. ${ }^{6}$ So, whilst in absolute terms most technologybased start-ups firms are found in core cities or in densely populated counties, in relative terms, start up rates are higher in the areas surrounding these regions. ${ }^{7}$ This applies especially to the Laender of east Germany, where there is a high concentration of technology-intensive start-ups in and around the large cities of, for example, Dresden, Leipzig and Berlin. These centres are particularly attractive for their proximity to facilities, such as technical colleges ('Fachhochschulen') and universities, as well as their favourable transportation links, satisfactory supply of intermediate products, large pools of highly qualified staff, and, of course, their large pools of potential founders (Felder et al., 1997b).

In addition, during the transformation process of the early nineties, a large share of the scientific personnel in universities and public R\&D organization in the east of Germany were made redundant. Simultaneously, the number of R\&D-personnel in industry in the former East Germany declined from about 86,000 in 1989 to 22,000 in 1993 (Spielkamp et al., 1997). Consequently, there has been a large supply of unemployed scientists and qualified workers, particularly in the vicinity of their former employers that were concentrated in the cities. These individuals are potential NTBF founders. From this perspective, the east German Laender of Thuringia and Saxony exhibit a high level of start-ups during the transformation process (see Table 6). In the east of Germany, concentrations of start-ups in technology-intensive industries are found in a belt extending along the north edge of the Mittelgebirge mountains and in the Thuringian Basin. This high-tech belt can be explained by its historic 'technology-based economic structure', as well as its traditional transportation links and business contacts with Eastern Europe and Bavaria. For example, until 1989 Saxony-Anhalt, Thuringia and Saxony were important locations for German firms like Carl Zeiss.

Beside the institutional and infrastructural conditions, there are other important factors which influence the choice of location of NTBF founders. One major factor is the size of the relevant market and the links to customers. This was pointed out by Kulicke (1987), who examined the importance of large and medium-sized firms, as well as public institutions, as customers for NTBFs. Large firms with more than 1000 employees were found to be very important customers for NTBFs; by contrast, public institutions are of minor importance as customers. Kulicke (1987) interprets

6 It should be noted that the scaling variable may exert a considerable influence on the extent of the suburbanization effects.

7 The recent development in the average number of start-ups in technology-intensive sectors reveals an increasing trend towards locations in the immediate vicinity of agglomerations. 
the lack of importance of public institutions as customers of NTBFs as a failure of the public spending policy.

Table 6: Start-ups in technology-intensive industries in Germany

\begin{tabular}{l|r|r|r}
\multicolumn{1}{c|}{ State } & \multicolumn{3}{|c}{ Number of start-ups (1993-1995) } \\
absolute & in percent & $\begin{array}{c}\text { in relation to 100,000 } \\
\text { labour force }\end{array}$ \\
\hline \hline 'West' of Germany & 71 & 2.1 & \\
Schleswig-Holstein & 50 & 1.5 & 4.1 \\
Hamburg & 176 & 5.2 & 4.6 \\
Lower Saxony & 20 & 0.6 & 3.6 \\
Bremen & 599 & 17.8 & 4.6 \\
North Rhine-Westphalia & 166 & 4.9 & 5.2 \\
Hesse & 93 & 2.8 & 4.3 \\
Rhineland-Palatinate & 359 & 10.7 & 3.8 \\
Baden-Wuerttemberg & 374 & 11.1 & 5.4 \\
Bavaria & 35 & 1.0 & 4.9 \\
Saarland & 162 & 4.8 & 5.0 \\
Berlin (East and West) & & & 7.1 \\
'East' of Germany & 199 & 5.9 & 12.2 \\
Brandenburg & 129 & 3.8 & 10.6 \\
Mecklenburg Western Pomerania & 442 & 13.1 & 15.7 \\
Saxony & 214 & 6.4 & 12.1 \\
Saxony-Anhalt & 278 & 8.3 & 17.3 \\
Thuringia & 3367 & 100 & - \\
\hline Total & \multicolumn{2}{|}{} \\
\hline \hline
\end{tabular}

Source: ZEW Formation Panel (East/West)

Table 7: NTBFs and their Clients

\begin{tabular}{|c|c|c|c|c|c|}
\hline \multirow[b]{2}{*}{ Clients } & \multicolumn{5}{|c|}{ Importance (in \%) } \\
\hline & very high & high & mid & low & very low \\
\hline Large Firms & 19 & 36 & 14 & 19 & 12 \\
\hline Mid-sized Firms & 8 & 16 & 14 & 23 & 39 \\
\hline Public Institutionsa) & 0 & 8 & 8 & 9 & 75 \\
\hline
\end{tabular}

a) Public Institutions include national offices with high demand (e.g. procuring agencies of the federal post administration, federal railways, federal armed forces) and further institutions with less demand 
(e.g. federal technical-physical institution, environmental authorities, Max Planck Society, Fraunhofer

Society, Nuclear Research Centers).

Source: Kulicke (1987, p. 182)

In the former East Germany there is a strong correlation between the proximity to customers in industry - especially large firms and public institutions and the regional concentration of start-ups in technology-intensive industries (Felder et al., 1997a). The large firms are mainly subsidiaries of West German or foreign firms which chose their location on the basis of factors such as the existing industrial structure, the regional endowment of qualified workers, the infrastructure and the availability of investment grants from government. In addition, there are still a lot of regions with unfavourable transportation linkages to important markets and potential markets in the east of Germany. In relation to this, it is important to recognise that NTBFs - especially older, established NTBFs, as opposed to newly founded NTBFs - are more likely to engage in exporting and international activities than other SMEs (Fritsch, 1990). This means that, for these firms, not only is access to local markets important, but so is access to international markets.

\subsection{Empirical results on the location of NTBFs}

Empirical results on the influence of regional characteristics on the number of new firms in very-high-tech industries (R\&D-Intensity above $8.5 \%$ ), high-tech industries (R\&D-Intensity between $3.5 \%$ and $8.5 \%$ ) and technology-intensive service sectors show that the presence of research facilities within counties has generally encouraged the formation of NTBFs with differences occuring according to the type of R\&D institution involved (company R\&D laboratories, universities and technical colleges, and non-university research institutions) and their particular specialization (Berger and Nerlinger, 1997; Felder et al., 1997b; Harhoff, 1995). Advantages appear to accrue especially from specialized departments in the fields of mechanical engineering, process engineering, electrical engineering and marine engineering. This also applies to $\mathrm{R} \& \mathrm{D}$ activities in non-university research institutions, where the number of scientists has tended to boost start-up incidence in west German counties. In addition, the empirical results by Berger and Nerlinger (1997) and Nerlinger (1996) show that industrial research activities appear to have no significant influence on the number of start-ups in technology-intensive sectors. ${ }^{8}$ This is a surprising result, because private companies with $R \& D$ operations have been claimed by other studies (e.g. Kulicke et al., 1993; Sternberg, 1988) to be important as incubator organizations. The very slight effect of private $R \& D$ operations on the number of NTBFs in the counties of west Germany is also

8 This result may be a consequence of heterogeneities in the composition of the R\&D staff in the firms. Analogously to the variables involved in the composition of the public-sector R\&D infrastructure, a disaggregation of the R\&D personnel broken down by the nature of their technological knowledge, tyeducational background and/or departmental affiliation, might prove illuminating (Nerlinger, 1996). 
contrary to the results reported by Felder et al. (1997a) for the east German Laender. However, it should be remembered that in the former East Germany the publicsector research infrastructure has undergone dramatic change in the last few years and numerous subsidy programmes are creating incentives for co-operative activities between innovative small and medium-sized firms and large companies (BMBF, 1996).

Overall, the hypothesis that the research infrastructure has a positive effect on the number of start-ups in the very-high-tech sector can be confirmed for public institutions (e.g. Universities, Institutes of the Fraunhofer-Society or Max-PlanckSociety). These research facilities can act as a springboard for scientific personnel to set up their own firm, but they can also be used as a potential source of cooperative partners and as a source of technological information and know-how. However, empirically it is difficult to distinguish between supply and demand-side factors. For example, universities and technical colleges have a role on both the supply side - through the provision of skilled workers and technological know-how, and a role on the demand side - as customers for the products and services provided by NTBFs. The various studies have also revealed, that besides the region's research infrastructure, its technological resources and industrial structure, other regional characteristics not specifically related to company start-ups in technologybased activities - such as the transport system, the regional level of taxes, and the average wage rates (Nerlinger, 1997; Berger and Nerlinger, 1997; Felder et al., 1997a) - may be important determinants of the regional rate of new firm formation in technology-intensive industries.

\section{Innovation and technology transfer by NTBFs}

In the context of new technology-based firms, the transfer of technology and entrepreneurial know-how from the 'parent' or 'incubator' organization (i.e., the founders' previous employer, which may have been an industrial firm, university or technical college, or research institute) and from other information sources is a central consideration (Lamont, 1972; Szyperski and Klandt, 1981). Moreover, the timing of this transfer of technology is of particular importance. For example, the technological and entrepreneurial knowledge contributed when a firm is formed will sometimes differ significantly from the knowledge that may be crucial in the period after start-up. In this context, Kulicke (1987) points out that, at start-up, there is usually a transfer of people as well as technology, whereas in the longer term, survival depends on the adaptation of and to technological innovations, for which contact with external sources of information and know-how is essential. Furthermore, the incubator organization should not be considered in isolation from the later sources of technology transfer. Studies by Beise et al. (1995) and Spielkamp and Beise (1995) indicates that there is a close relationship between the incubator organization and the channels and networks used after start-up to access to technological knowledge or technology transfer mechanisms. These studies show 
that the probability of a co-operative contact with a university is higher if the CEO of the technology-based firm has a Ph.D. Interestingly, however, there appears to be no difference between firms where the CEO has a primary academic qualification (i.e. a first degree) or a non-academic qualification. It seems, therefore, that the continuous transfer of research-based knowledge into companies depends on the firm's adaptive capacity, the knowledge of how to obtain knowledge from universities, and the prior experience of the decision-makers concerned.

\subsection{Technology transfer through the incubator organization}

When technology is transferred through an incubator organization, entrepreneurial, as well as technological, knowledge is transferred. In the period immediately after Germany's reunification, spin-off firms were ascribed a special role in the process of the transformation of the former East Germany. Felder et al. (1997b) hypothesised that the technical knowledge and the multi-faceted experience of engineers and academics whose research institute ceased to exist or which were threatened by closure could be gainfully employed by setting up technologyintensive firms. However, the experience has demonstrated that whilst an understanding of the technologies to be developed is a necessary condition for the establishment of a technology-based firm, it is not a sufficient condition for the firm's survival; for survival also requires an understanding of how to operate within free market conditions.

The extent of technical and entrepreneurial knowledge transferred depends largely on the type of incubator organization involved. Kulicke (1987) has shown that roughly two thirds of the total number of founders of innovative firms 9 were previously employed in industrial companies before becoming self-employed. In 1987, around a quarter of the new entrepreneurs came from universities, technical colleges or state research institutes, but interestingly this proportion had grown to around a third by 1993 (Kulicke et al., 1993). Similar findings are provided by Heinzel (1990), Sternberg (1989) and Sternberg et al. (1996).

Table 8: The significance of incubator organizations

\begin{tabular}{l|c}
\multicolumn{1}{c|}{ Type of organization } & Number of founders \\
\hline \hline Large firm (more than 500 employees) & $32.2 \%$ \\
Medium-sized firm (less than 500 employees) & $33.6 \%$ \\
Universities & $15.4 \%$ \\
\hline \hline
\end{tabular}

9 Kulicke (1987) analyses all firms which have been promoted in the pilot project 'Promotion of New Technology-based Firms'. This scheme was initiated by the Federal Research Ministry (BMFT). 


\begin{tabular}{l|l} 
Technical colleges & $2.7 \%$ \\
State Research Institutes & $6.0 \%$ \\
Own Firm & $6.7 \%$ \\
Other & $3.4 \%$ \\
\hline \hline
\end{tabular}

Source: Kulicke (1987, p. 118)

A study by Kulicke (1987) and Kulicke et al. (1993) of the functional background of founders of innovative firms found that 79 percent of founders have experience in $R \& D, 32$ percent in sales, and 28 percent in production, but very few firms were established by individuals experienced in accounting and finance. Similar results for NTBFs in east Germany are reported by Pleschak et al. (1994).

\subsection{Technology transfer after start-up}

The innovative focus of NTBFs encourages them to exchange knowledge and cooperate frequently with external research institutions. This involves not only a transfer of technological knowledge, but also a transfer of technology in the form of qualified personnel. Kulicke (1987) reports that around half of all NTBFs surveyed use external sources of information. The firms involved also stated the purpose and ascribed a significance to their external contacts and sources of information. It emerged that state research institutes and customers' relationships with the firms' development centres play major roles whilst in most cases, technology transfer through the recruitment of qualified personnel involves universities and technical colleges.

Table 9: Contact frequency between firms in technology and innovation centres and regional $R \& D$ institutions

\begin{tabular}{l|c}
\multicolumn{1}{c|}{ Contacts } & Frequency \\
\hline \hline No contacts with R\&D institutions & $26.2 \%$ \\
Contacts with R\&D institutions overall & $73.8 \%$ \\
• by type of R\&D institution: & \\
\hline University & $82.7 \%$ \\
Technical college & $27.6 \%$ \\
Non-University Research Institutions & $21.3 \%$ \\
R\&D department of private firms & $18.9 \%$ \\
• by type of contact: & \\
\hline Exchange of information & $37.7 \%$ \\
Accepting (sub)contracts & $42.5 \%$ \\
Acquisition of personnel & \\
\hline \hline
\end{tabular}




\begin{tabular}{l|l} 
Favourable use of expensive equipment & $26.0 \%$ \\
Other & $11.8 \%$ \\
\hline \hline
\end{tabular}

Source: Sternberg (1988, p. 200), Sternberg et al. (1996)

Similar results are reported by Sternberg (1988) and Sternberg et al. (1996) who surveyed firms at technology and innovation centres in both the west and east of Germany. More than 70 percent of the innovative firms surveyed stated that they were in contact with regional R\&D institutions such as universities and technical colleges. Only 26 percent of the firms said they had no contacts with regional R\&D institutions. Universities and technical colleges play a major role in this context, whereas non-university research institutions and corporate $R \& D$ departments are of only modest significance as sources of information. A breakdown of contacts by type revealed that, apart from the exchange of knowledge and information, innovative firms also attach importance to acquiring personnel and accepting R\&Dintensive contracts.

A survey of innovative company founders conducted by Picot et al. (1989), in which innovative firms are defined as spin-offs from universities and technical colleges, revealed their low utilization of innovation consultants as sources of advise and support with regard to the companies R\&D activities. This survey also revealed that most innovative company founders which used these services were not impressed by the consultancy they received. Somewhat higher ratings were accorded to management consultants, whose services were also used more frequently. However, the high fees charged by management consultants were seen as a barrier to the use of these services by many new and small firms. Picot et al. (1989) also found that NTBFs tend to use banks and technology centres with higher than average frequency, and their support received high ratings. Public-sector agencies (such as the Chambers of Industry and Commerce) were also highly rated and frequently used, whereas research institutes were accessed much less frequently. With respect to these differences, numerous initiatives at both the Laender and federal government levels now exist which aim to improve the effectiveness of public-sector research institutions as providers of assistance for innovative small and medium-sized firms. ${ }^{10}$

\section{$5 \quad$ Support and Promotion of Research \& Development and NTBFs}

Numerous studies have indicated that many factors, like Germany's tax system, disadvantageous legal, political and institutional framework conditions and its

10 One important reason for the increased focus of universities and research institutions on the interests of small and medium-sized firms has been the decline in subsidies from the Laender and the federal government as well as the declining volume of projects with large firms. 
insolvency laws, hamper the creation and development of innovative young firms (Little, 1977, Fraunhofer Institute fuer Systemtechnik und Innovationsforschung and Segal Quince Wicksteed, 1988; Kasch, 1985; Gerybadze, 1991). There is also criticism of the banking system ${ }^{11}$, which shows a clear reluctance to devise financial packages for NTBFs. This is also the case for the venture capital market, although this has improved over recent years, primarily because of government initiatives

\subsection{R\&D Expenditures in Germany: An Overview}

Providing a detailed overview of the initiatives that exist in Germany to subsidise innovative young firms is not an easy task. Firstly, many of the programmes are not aimed specifically at these firms and, secondly, the responsibility for the programmes is distributed amongst several federal ministries, Laender ministries and autonomous (research) organizations. This is also reflected in the distribution amongst sectors of government $R \& D$ expenditure. It is clear that most $R \& D$ is performed by private industry, followed, a long way behind, by the Laender and the federal governments. Comparing the research budgets between 1991 and 1995 reveals the share of Laender and the federal government funding has increased to maintain and expand efficient R\&D capacities, especially in the former East Germany (BMBF, 1996). In 1991, the new Laender of east Germany and East Berlin, accounted for 9.6 percent of the federal government's total R\&D expenditure, but by 1994 this proportion had nearly doubled to 17.7 percent (BMBF, 1996). ${ }^{12}$

Table 10: R\&D Expenditure of the Federal Republic of Germany by Financing Sectors and as a percentage of GNP (1991-1995)

\begin{tabular}{l|r|r|r|r|r}
\multicolumn{1}{c|}{ Financing Sectors } & 1991 & 1992 & 1993 & 1994 & 1995 \\
\hline \hline Federal Government (DM million) & 16,926 & 17,339 & 16,860 & 16,348 & 16,820 \\
Index (1991 = 100) & 100 & 102 & 100 & 97 & 99 \\
\% of total R\&D Expenditure & 22.1 & 22.1 & 21.4 & 20.7 & 20.8 \\
\hline Laender (DM million) & 12,287 & 12,888 & 13,546 & 14,340 & 15,060 \\
Index (1991 = 100) & 100 & 105 & 110 & 117 & 123 \\
\% of total R\&D Expenditure & 16.0 & 16.4 & 17.2 & 18.1 & 18.6 \\
\hline Industry (DM million) & 46,998 & 47,945 & 48,023 & 48,090 & 48,900 \\
Index (1991 = 100) & 100 & 102 & 102 & 102 & 104
\end{tabular}

11 Kasch (1985) describes the typical procedure adopted by a bank (Deutsche Bank AG) in connection with the financing of innovative firms.

12 In comparison, the figures for the three German Laender with the highest shares in the federal government's R\&D expenditure are: Baden-Wuerttemberg (15.0 percent), Bavaria (21.9 percent) and North Rhine-Westphalia (15.6 percent). Private R\&D expenditure in these three Laender are also far above the amount of private R\&D spending in the east of Germany as a whole. 


\begin{tabular}{l|r|r|r|r|r} 
\% of total R\&D Expenditure & 61.4 & 61.1 & 61.0 & 60.8 & 60.3 \\
\hline $\begin{array}{l}\text { Private Non-Profit-Making Institutions (DM } \\
\text { million) }\end{array}$ & 380 & 285 & 241 & 260 & 260 \\
Index (1991 = 100) & 100 & 75 & 63 & 68 & 68 \\
\% of total R\&D Expenditure & 0.5 & 0.4 & 0.3 & 0.3 & 0.3 \\
\hline Total R\&D Expenditure (DM million) & 76,591 & 78,457 & 78,670 & 79,038 & 81,040 \\
Index (1991 = 100) & 100 & 102 & 103 & 103 & 106 \\
\% of GNP & 2.66 & 2.54 & 2.49 & 2.39 & 2.35 \\
\hline \hline
\end{tabular}

Source: BMBF (1996, p. 60)

Three ministries are responsible for the bulk of federal government's R\&D expenditures (1994: 16,348 DM million), these are: the Federal Ministry of Economics (1994: 7.1 percent), the Federal Ministry of Defence (1994: 16.2 percent) and the Federal Ministry for Education and Science, Research and Technology (1994: 64.9 percent). The proportion of the federal government's R\&D expenditure allocated to private firms and enterprises has fallen sharply, from 42.8 percent in 1981 to 27.2 percent in 1994, whereas there have been very sizeable increases in some government departments, non-profit-making organizations and other institutions. Overall, the federal government made R\&D funds totalling 4,675 million DM available to trade and industry in 1995, of which the Federal Ministry of Economics (BMWi) accounted for 702 million DM, the Federal Ministry of Defence (BMVg) 2,316 million DM, and the Federal Ministry for Education, Science, Research and Technology (BMBF) for 1,455 million DM.

\subsection{Promotion of R\&D in Trade and Industry by Government}

Most of the federal government's funding for trade and industry is channelled through direct and indirect subsidies and promotional initiatives. Direct project support is concentrated on specific technologies, such as microsystems engineering, biotechnology or information technology, but there is a requirement for a detailed examination of every project proposal. It is notable that in Germany direct public support is more focused on specific areas of technology rather than on specific types of firms, such as SMEs or NTBFs. The underlying idea being the promotion of spill-over effects from the firms that use these technologies to those (particularly small and medium sized firms) which do not.

Indirect measures ${ }^{13}$ provide non-technology-specific impetuses for intensifying firms' research and development efforts, but they are largely aimed at promoting

13 In addition, there are indirect-specific measures with simplified application and implementation procedures which are usually implemented under specialised programmes and intended to disseminate new technologies through small and medium-sized firms (BMBF, 1996). 
R\&D in small and medium-sized firms. As with the direct schemes, the indirect promotion measures are essentially legitimised by spill-over effects. In addition, it is argued that indirect promotion measures overcome problems of indivisibility in respect of R\&D and innovation. For example, a small NTBF may need a highly qualified technician for a certain time period, but it may not be able to afford to employ the technician on a full-time basis. Programmes such as the 'R\&Dpersonnel Costs Subsidy' (and since 1992, the 'R\&D-personnel Subsidy East' - for 'East' Germany) from the Federal Ministry for Economic (BMWi) and the 'Research-personnel Increase Promotion' from the Federal Ministry for Education, Science, Research and Technology (BMBF) are intended to overcome these disadvantages, especially in SMEs. It is also argued that indirect promotion schemes are necessary because of existing financing constraints on (innovative) SMEs. One reason for theses constraints is the small size of the venture capital market in relation to GDP in Germany and in comparison with other European countries (Jager, 1996).

The federal government's $R \& D$ expenditure figures for indirect promotional programmes in 1991 reveal a high expenditure on special R\&D depreciation allowances and R\&D investment subsidies. This exceptional support was for the ongoing transformational process in the east of Germany after reunification in 1989. The inclusion of this support meant that total R\&D expenditure in 1991 reached a record level of 720.6 million DM. Since 1992 Federal expenditure on indirect R\&D initiatives continued to rise, from 455.4 million (in 1992) to 671.6 million DM in 1995. This increase reflects measures designed to stimulate and intensify technology transfer and co-operation activities between industry and research institutions, especially in the east of Germany.

Table 11: Indirect Measures for the Promotion of Research and Development in Trade and Industry

\begin{tabular}{l|r|r|r|r|c}
\multicolumn{1}{c|}{ Schemes (responsible ministry) } & 1991 & 1992 & 1993 & 1994 & 1995 \\
\hline \hline $\begin{array}{l}\text { Potential-oriented Scheme } \\
\text { R\&D-personnel Costs Subsidy (BMWi) } \\
\text { (since 1992 R\&D-personnel Subsidy East) }\end{array}$ & 1.9 & 47.9 & 91.8 & 67.1 & 109.6 \\
$\begin{array}{l}\text { Research-personnel Increase Promotion (BMBF) } \\
\text { R\&D Investment Allowance (Tax-related measure }\end{array}$ & 30.3 & 25.9 & 21.1 & 18.7 & 17.5 \\
pursuant to sect. 4 of the Investment Grant Act) & & - & - & - & - \\
$\begin{array}{l}\text { Special R\&D depreciation (Tax-related measure } \\
\text { pursuant to sect. 82d of the Ordinance Regulating the }\end{array}$ & 200.0 & - & - & - & - \\
Income Tax Law) & & & & & \\
\hline $\begin{array}{l}\text { Schemes to Support Cooperation between Industry and } \\
\text { Science }\end{array}$ & & & & & \\
Industrial Cooperative Research (BMWi) & 199.8 & 198.1 & 169.6 & 169.9 & 169.9 \\
Contract Research and Development (BMBF) & 31.7 & 44.3 & 70.3 & 60.8 & 85.5 \\
\hline \hline
\end{tabular}


Technology Transfer and Research Cooperation (BMBF)

Technology Transfer Pilot Projects (including Patent Inspection Offices) (BMWi)

\begin{tabular}{l|r|r|r|r|r}
\hline Innovation Promotion (BMWi) & 0.2 & 8.4 & 50.6 & 80.0 & 82.0 \\
\hline Promotion of New Technology-Based Firms (BMBF) & 45.9 & 77.0 & 81.7 & 67.2 & 64.1 \\
\hline $\begin{array}{l}\text { R\&D Loans for Small and Medium Enterprises to } \\
\text { promote the Application of new Technologies (BMBF) }\end{array}$ & - & - & - & 2.2 & 5.9 \\
\hline $\begin{array}{l}\text { Pilot Scheme to Support Information Retrieval from } \\
\text { Databases (BMBF) }\end{array}$ & 2.8 & 8.1 & 6.2 & 4.7 & 2.7 \\
\hline Total & 720.6 & 455.4 & 543.1 & 564.1 & 671.6 \\
\hline
\end{tabular}

BMBF: Federal Ministry for Education, Science, Research and Technology BMWi: Federal Ministry of Economics

Source: BMBF (1996, p. 97)

Federal funding in support of new technology-based firms has also increased, complemented by additional programmes from the EC and almost all the German Laender. ${ }^{14}$ There is, however, a huge variety and heterogeneity in these schemes, particularly with regard to the criteria for the promoted technologies (e.g. microelectronics, biotechnology), industry sectors or firm characteristics (e.g. number of employees, owner structure). The primary aim of these NTBFs promotion programmes in the Bundeslaender is to increase of the number of employees; the diffusion and adoption of new technologies is the secondary consideration. ${ }^{15}$

A second important field of activity for public initiative is related to the financial constraints faced by NTBFs. During 1995 and 1996, the Federal Ministry of Economics (BMBF) started several new programmes for promoting capital investment in innovative young firms, including a 'Venture Capital for small technology-based firms' scheme, which is not only designed to support the R\&D phase but also the market launch phase of new product development in small technology-based firms. ${ }^{16}$ This new federal venture-capital programme considers the experiences of the earlier programmes which showed considerable success with regard to the survival and growth of the NTBFs involved. These public measures in support of NTBFs are particularly important because in Germany the private seed

14 However, recent discussions and evaluations have shown a severe lack of transparency and consistency within and between the various programmes.

15 Due to the regional industry structure and specialisation in strategic technologies, these programmes often focus on technologies like information technology, biotechnology, microelectronics or materials research

16 Similar considerations are behind the programme 'Promotion and support of new technology-based firms', focusing on NTBFs in the east German Laender, through which intensive consultancy services are additionally provided in order to formulate a viable firm. 
and venture capital markets are still in their infancy - especially in comparison with other countries. German NTBFs are therefore relatively unaware of the potential of this means of financing. 
Table 12: Early Stage Investment as a percentage of Total Venture Capital Investment

\begin{tabular}{l|l|r|r|r|r|r} 
& \multicolumn{1}{|c|}{ County } & 1990 & 1991 & 1992 & 1993 & 1994 \\
\hline \hline \multirow{2}{*}{ Seed: } & Germany & 0.6 & 2.5 & 1.2 & 1.2 & 2.2 \\
& Netherlands & 2.0 & 2.0 & 0.9 & 1.0 & 2.0 \\
& OECD Europe & 0.7 & 1.0 & 0.6 & 0.5 & 0.7 \\
& United States & 3.1 & 4.1 & 2.9 & 6.9 & 4.2 \\
\hline \multirow{2}{*}{ Start-up: } & Germany & 5.7 & 4.4 & 6.3 & 7.3 & 8.1 \\
& Netherlands & 7.0 & 6.0 & 7.0 & 9.0 & 11.0 \\
& OECD Europe & 7.7 & 5.9 & 5.3 & 4.4 & 5.0 \\
& United States & 7.4 & 5.6 & 8.2 & 7.1 & 14.9 \\
\hline \hline
\end{tabular}

Early stage financing is related to the provosion of risk capital in behalf of product development (SeedStage) and the establishment of enterprises (Start-up-Stage)

In relation to GDP the German VC-market appears to be very small: Germany: $2 \%$, France: $4 \%$; United Kingdom: $11 \%$

Source: Jager (1996, p. 18)

It may be surprising that survey results find that venture capital (VC) is perceived by firms to be of only minor importance, but Picot et al. (1989) attribute this to the lack of awareness of VC amongst most NTBF founders. This, in turn, may be because VC-firms often concentrate on a select group of particularly promising new ventures (Laub, 1988). Others studies have also pointed out that a large share of the firm-founders and owners do not want to relinquish control and are therefore reluctant to sell some of their share capital to VC firms (Fetzer, 1990). The impact of the numerous public venture capital promotion schemes in Germany in recent years has been to improve the supply of venture capital for new technology-based firms (BMBF, 1996). The amount of venture capital, for example, rose eightfold between 1983 and 1995. However, the share of venture capital in relation to the Geman GDP is still significantly smaller than that of many other European countries (Jager, 1996). For example, in 1994, the figure was 2 percent in Germany, compared to 4 percent in France and 11 percent in UK. These differences show that much more action (including altering the fiscal framework) is necessary if the venture capital market is to be improved and NTBFs are to gain access to this sort of capital.

\section{Summary and Topics for further Research}

This paper has sought to provide an overview of some of the recent research on New Technology Based Firms in Germany. Clearly, space limitations have limited the detail of the discussion, and our choice of topics and the weight we have put on them has been influenced by our own experience. Nevertheless, the survey has covered issues from firm formation dynamics, the regional distribution and location characteristics of NTBFs, the participation of these firms in technology transfers, 
and their participation in public support programmes. It has been shown that after the decline in the number of technology-based start-ups that was apparent between 1990 and 1992, there has been a small increase in the annual number of new firm formations in the high-tech industries and in technology-intensive services, but it is also apparent that, compared with the number of formations in the late 1980s, the number of firm formations in the very-high-tech manufacturing sectors has remained at a lower level since 1992. With regard to the results of analyses on the regional clustering of NTBFs and their locational considerations, one of the major findings was that the regional $R \& D$ endowment of universities, technical colleges and non-university R\&D-labs has a large impact on the number of new firms in the region, but that this impact also varies with the institute's field of specialisation. In contrast, the R\&D activities of private firms do not appear to have an influence on the number of NTBFs in a region. The importance of the regional endowment of R\&D facilities is also important with regard to technology transfer. The perceived importance of NTBFs for technology transfer and for the creation of employment is indicated by the number and the volume of public promotion schemes which are offered by federal ministries as well as by the ministries and institutions of the Bundeslaender. However, due to the huge volume and sometimes confusing complexity of the supporting schemes, a lot of small and medium-sized firms have neither the time nor money to gather and process all the available information about these programmes. Consequently, they may not apply for the support that is available at the level of the Laender, the federal level, or at the EC level. As a response to this, a reduction and simplification of the support schemes is planned in Germany. Apart from benefiting the firms, this may also benefit providers of support, including banks, by the imposition of clear standards of support.

We end this paper with some suggestions for further research on NTBFs, but these suggestions are restricted not only to the German case. We suggest that further research should address the medium and long-run development of NTBFs as well as their contributions to the development of new industries and new technologies. This is especially important in light of the increasing government incentives for NTBFs. Firstly, start-up rates have traditionally been thought to be much higher in the US than in some European countries, including Germany. It is also supposed that mortality rate is higher in the US. On the one hand, higher entry and exit rates can be viewed as reflecting Schumpeterian dynamics where many ideas are tried, but only the best survive. On the other, high exit rates imply a waste of resources if the surviving firms do not compensate for the destruction of value lost through the closure of firms. For these reasons, careful studies of survival and growth rates of start-up cohorts are needed, and we suggest these be made a priority for future research. Second, given the large differences in the means of financing start-ups in the Anglo-American societies and in other countries, such as Germany, international comparisons of the share of successful firms (i.e., the share of surviving and the proportion of fast growing companies) should shed light on the 
importance of these means of financing in economic performance. This will enhance our knowledge of the relationship between the financial and the productive parts of the economy which is of much wider interest than just NTBFs research. In relation to this, comparing the survival rate of NTBFs with other firms is important. If it turns out that NTBFs have higher survival rates we have further evidence for the favourable role of technological innovation in the development of market economies. Thirdly, internationalisation seems to be especially strong in the markets for high-technology products and services. We should therefore expect NTBFs to be severely affected by increasing international competition in their markets and to be at the forefront of the internationalisation process within the small and medium sized enterprise (SME) sector in terms of export development. Indeed, there as some studies which indicate that export activities and export shares are larger in NTBFs than other SMEs, but we suggest that more systematic evidence on the internationalisation of NTBFs and SMEs should be high on the research agenda and theoretical research on this topic should also be encouraged. 


\section{References}

Beise, M., G. Licht und A. Spielkamp (1995), Technologietransfer an kleine und mittlere Unternehmen: Analysen und Perspektiven fuer Baden-Wuerttemberg, Schriftenreihe des ZEW, No. 3, Baden-Baden.

Beise, M., M. Falk, G. Licht und F. Pfeiffer (1997), Innovationen und Humankapital der Unternehmen in den 90er Jahren, Beitrag zur Berichterstattung zur technologischen Leistungsfähigkeit Deutschlands 1996, Zentrum für Europäische Wirtschaftsforschung, Mannheim.

Bellmann, L, D. Harhoff und N. Schulz (1997), Zur Analyse von Gruendungen und Schliessungen auf der Basis der IAB-Beschaeftigtenstatistik, Nuernberg, Mannheim, Wuerzburg, mimeo.

Berger, G. und E. Nerlinger (1997), Informationstechnologien in Deutschland: Marktentwicklung und Unternehmensgruendungen, in: Harhoff, D. (ed.), Unternehmensgruendungen: Empirische Analysen fuer die alten und neuen Bundeslaender, Vol. 7, S. 151-186, BadenBaden.

Berndts, P. und D.-M. Harmsen (1985), Technologieorientierte Unternehmensgruendungen in Zusammenarbeit mit staatlichen Forschungseinrichtungen, Koeln.

Birch, D. L. (1979), The Job Generation Process, M.I.T. Program on Neighbourhood and Regional Change, Cambridge.

BMBF (1996), Bundesforschungsbericht 1996, Bonn.

Davis, S. J., J. Haltiwanger und S. Schuh (1996b), Small Business and Job Creation: Dissecting the Myth and Reassessing the Facts, Small Busainess Economics, Vol. 8, S. 297-315.

Felder, J., A. Fier und E. Nerlinger (1997a), High Tech in den neuen Laendern: Unternehmensgruendungen und Standorte, Zeitschrift fuer Wirtschaftsgeographie, Vol. 1, Jg. 41, S. 117.

Felder, J., A. Fier und E. Nerlinger (1997b), Im Osten nichts Neues? Unternehmensgruendungen in High-Tech Industrien, in: D. Harhoff (ed.), Unternehmensgruendungen - Empirische Analysen fuer die alten und neuen Bundeslaender, Vol. 7, S. 73-110, Baden-Baden.

Fetzer, R. (1990), Analyse internationaler Unterschiede im Volumen und in der Struktur von Venture-Capital-Aufkommen und -Anlage: Analysen zur Strategie ausgewählter Akteure im Netzwerk der jungen Technologieunternehmen, Berlin.

Fraunhofer Institut fuer Sytemtechnik und Innovation (ISI) und Segal Quince Wicksteed (1988), New Technology-based Firms in Britain and Germany: A Review, in: Anglo-German Foundation in collaboration with Bundesministerium fuer Forschung und Technologie and the Department of Trade and Industry, New Technology-Based Firms in Britain and Germany, London, p. 1-32.

Fritsch, M. (1990), "Wachstumsmotor" junge Technologieunternehmen?, Zu Besonderheiten der Beschaeftigungsentwicklung im Verarbeitenden Gewerbe der Bundesrepublik Deutschland, Internationales Gewerbearchiv, Heft 3, p. 147-161.

Gerlach, K. and J. Wagner (1997), Analysen zur Nachfrageseite des Arbeitsmarktes mit Betriebspaneldaten aus Erhebungen der amtlichen Industriestatistik: Ein Ueberblick ueber Ansaetze und Ergebnisse fuer niedersaechsische Industriebetriebe, , in: Kuehl, J., M. Lahner and J. Wagner (eds.), Die Nachfrageseite des Arbeitsmarktes: Ergebnisse aus Analysen mit deutschen Firmenpaneldaten, Beitraege zur Arbeitsmarkt- und Berufsforschung, BeitrAB 204, Nuernberg, p. 11-82. 
Gerybadze, A. (1991), Marktwirtschaft und innovative Unternehmensgruendungen: Erfahrungen aus dem Modellversuch "Foerderung technologieorientierter Unternehmensgruendungen (TOU), in: Oberender, P. und M. E. Streit, Marktwirtschaft und Innovation, Baden-Baden, p. 123-157.

Grotz, R. (1989), Technologische Erneuerung und technologieorientierte Unternehmensgruendungen in der Industrie der Bundesrepublik Deutschland, Geographische Rundschau 5, p. 266-272.

Harhoff, D. (1995), Firm Formation and Regional Spillovers-Evidence from Germany, ZEWDiscussion Paper 95-11, Mannheim.

Heinzel, W. (1990), Foerderkonzepte fuer technologieorientierte Unternehmensgruendungen: Probleme und Erfolge der bisherigen Foerderungspolitik, in: Berger, J, V. Dohmeyer und M. Funder (eds.), Kleinbetriebe im wirtschaftlichen Wandel, Frankfurt, p. 269-288.

Henckel, D. und B. Hollbach (1991), Neue Techniken auf alten Flaechen: Der Beitrag technikintensiver Betriebe zur Revitalisierung des Ruhrgebietes, Berlin.

Jager, N. de (1996), Financing small- and medium-sized enterprises (SMEs), Paper presented at the Workshop "Charting Rhineland: German and Dutch Institutions in a Changing World", DIA German Institute Amsterdam, Amsterdam, 1.11.1996.

Kasch, K. (1985), Financing of Innovation, in: Allesch, J. und H. Fiedler, Management of Science Parks and Innovation centers, Documentation of the International Workshop held in Berlin, West Germany at the "Berlin Centre for Innovation and New Entreprises" (BIG) from 29-30 November, Berlin, p. 157-160.

Koschatzky, K., H. Grupp, U. Gundrum, S. Hinze und U. Kuntze (1992), High-Tech-Unternehmen in der Region Rhein-Main, Grundlagenstudie im Auftrag des Umlandverbandes Frankfurt und der Wirtschaftsfoerderung Frankfurt GmbH, Karlsruhe.

Kulicke, M. (1987), Technologieorientierte Unternehmen in der Bundesrepublik Deutschland: Eine empirische Untersuchung der Strukturbildungs- und Wachstumsphase von Neugruendungen, Frankfurt.

Kulicke, M., K. Bayer, G. Braeunling, H. J. Ewers, A. Gerybadze, M. Mayer, R. Mueller, T. Wein und U. Wupperfeld (1993), Chancen und Risiken junger Technologieunternehmen: Ergebnisse des Modellversuchs "Foerderung technologieorientierter Unternehmensgruendungen", Schriftenreihe des Fraunhofer-Instituts fuer Systemtechnik und Innovationsforschung (ISI), Heidelberg.

Lamont, L. (1972), Entrepreneurship, Technology, and the University, R\&D Management, Vol. 2, 3, p. 119-123.

Laub, U. (1988), Zur Bewertung innovativer Unternehmensgruendungen im institutionellen Zusammenhang: Eine empirisch gestuetzte Untersuchung, unveroeffentlichtes Manuskript, Muenchen.

Little, A. D. (1977), New Technology-Based Firms in the United Kingdom and the Federal Republic of Germany: A Report prepared for the Anglo-German Foundation for the Study of Industrial Society, London.

Nerlinger E. (1995), Die Gruendungsdynamik in technologieorientierten Wirtschaftszweigen: Eine Analyse der IAB-Beschaeftigtenstatistik, ZEW-Discussion Paper No. 95-17, Mannheim.

Nerlinger, E. (1996), Firm Formations in High-Tech Industries: Empirical Results for Germany, ZEW-Discussion Paper, Nr. 96-07, Mannheim. 
Nerlinger, E. (1997), Unternehmensgruendungen in High-Tech Industrien: Analysen auf Basis des ZEW-Gruendungspanel (West), in: Kuehl, J., M. Lahner und J. Wagner (eds.), Die Nachfrageseite des Arbeitsmarktes: Ergebnisse aus Analysen mit deutschen Firmenpaneldaten, Beitraege zur Arbeitsmarkt- und Berufsforschung, BeitrAB 204, Nuernberg, S. 135-166.

Nerlinger, E. und G. Berger (1995a), Technologieorientierte Industrien und Unternehmen: Alternative Definitionen, ZEW-Discussion Paper, Nr. 95-20, Mannheim.

Nerlinger, E. und G. Berger (1995b), Regionale Verteilung technologieorientierter Unternehmensgruendungen, ZEW-Discussion Paper, Nr. 95-23, Mannheim.

Picot, A., U.-D. Laub und D. Schneider (1989), Innovative Unternehmensgruendungen: Eine oekonomisch-empirische Analyse, Berlin.

Pleschak, F., H. Sabisch and U. Wupperfeld (1994), Innovationsorientierte kleine Unternehmen, Wiesbaden.

Sachverstaendigenrat (1993), Sachverstaendigenrat zur Begutachtung der gesamtwirtschaftlichen Entwicklung: Zeit zum Handeln-Antriebskraefte staerken, Jahresgutachten 1993/1994, Stuttgart.

Spielkamp, A. und M. Beise (1995), Innovationsprozesse in Unternehmen und Technologietransfer, Statement fuer den Workshop "Regionale Entwicklungsimpulse von Hochschulen, insbesondere von neu errichteten Fachhochschulen" der Fachhochschule Gelsenkirchen am 23. Maerz 1995, Mannheim, mimeo.

Spielkamp, A. et al. (1997), Zukunft der industriellen Forschung und Entwicklung in Ostdeutschland: Analyse der Situation, Probleme und der Perspektiven der FuE in der ostdeutschen Wirtschaft, Studie im Auftrag des Bundesministeriums fuer Bildung, Wissenschaft, Forschung und Technologie, Mannheim.

Sternberg, R. (1988), Technologie- und Gruenderzentren als Instrument kommunaler Wirtschaftsfoerderung: Bewertung auf der Grundlage von Erhebungen in 31 Zentren und 177 Unternehmen, Dortmund.

Sternberg, R. (1989), Innovation centres and their importance for the growth of new technologybased firms: experience gained from the Federal Republic of Germany, Technovation, Vol. 9, p. 681-694.

Sternberg, R. (1995), Technologiepolitik und High-Tech Regionen im Vergleich: Ein internationaler Vergleich, Muenster.

Sternberg, R., H. Behrendt, H. Seeger und C. Tamasy (1996), Bilanz eines Booms: Wirkungsanalyse von Technologie- und Gruenderzentren in Deutschland, Dortmund.

Szyperski, N. und H. Klandt (1981), Wissenschaftlich-technische Mitarbeiter von Forschungs- und Entwicklungseinrichtungen als potentielle Spin-off-Gruender: Eine empirische Studie zu den Entstehungsfaktoren von innovativen Unternehmensgruendungen im Lande Nordrhein-Westfalen, Opladen.

Verband der Vereine Creditreform (1985), Gruenderszene- nur Stueck fuer Stueck, Wirtschaftswoche, No. 3, p. 55. 